\title{
Genetic variation of TNF- $\alpha$ and IL-10, IL-12, IL-17 genes and association with torque teno virus infection post hematopoietic stem cell transplantation
}

\author{
M. RAMZI ${ }^{1}$, N. ARANDI ${ }^{1}$, T. ZAREI ${ }^{1}$, M. IRAVANI SAADI ${ }^{1 *}$, \\ R. YAGHOBI ${ }^{2}$, M. MOGHADAM ${ }^{1}$, B. GERAMIZADEH ${ }^{2}$
}

${ }^{1}$ Hematology Research Center and ${ }^{2}$ Organ Transplant Research Center, Shiraz University of Medical Sciences, Shiraz, Iran

Received May 23, 2018; revised July 25, 2018; accepted May 9, 2019

\begin{abstract}
Summary. - Little is known about the role of genetic variation in the genes for cytokines and susceptibility to viral infection especially torque teno virus (TTV) following allogeneic hematopoietic stem cell transplantation. In this study, the association between interleukin-12, interleukin-17, interleukin-10 (IL-12,-17,-10) and tumor necrosis factor $\alpha$ (TNF- $\alpha$ ) polymorphisms was evaluated in patients with TTV infection who underwent allogeneic hematopoietic stem cell transplantation from South of Iran. The single nucleotide polymorphisms in the cytokine genes including IL-12 (-1188A/C), IL-17 (-197G/A), IL-10 (-1082G/A, -819C/T and -592C/A) and TNF- $\alpha(-308 \mathrm{G} / \mathrm{A})$ were analyzed by PCR-RFLP methods. While our results did not show any association between IL-17, IL-12 and IL-10 (-819C/T and -1082G/A) polymorphisms and TTV infection status, heterozygote genotype of IL-10 (-592C/A) had direct correlation with TTV infection and A allele of TNF- $\alpha$ (-308G/A) showed a protective effect against TTV infection $(\mathrm{P}=0.05$ and $\mathrm{P}=0.025$, respectively). Within the group of patients who experienced acute graft-versus-host disease, the AA genotype and the A allele of IL-17 (-197 G/A) were significantly higher in non-infected patients compared to infected ones ( $p=0.024$ and $p=0.057$, respectively). It was also observed that among infected patients, the GG genotype of IL-17 and AA genotype of TNF- $\alpha$ were significantly increased in hematopoietic stem cell transplanted patients with low grade (grade I+II) acute graftversus-host disease compared to high grade (grade III and IV) disease ( $p=0.056$ and $p=0.056$, respectively). Taken together, genetic variation of IL-10 (-592C/A) and TNF- $\alpha$ (-308G/A) genes might be associated with susceptibility to TTV infection post hematopoietic stem cell transplantation.
\end{abstract}

Keywords: TNF- $\alpha$; interleukins; torque teno virus (TTV); hematopoietic stem cell transplantation (HSCT); graft versus host disease (GvHD)

\section{Introduction}

Allogeneic hematopoietic stem cell transplantation (alloHSCT) is an established treatment choice for several hematological diseases. However, infections and graft-versus-host disease (GvHD) are major complications often occurring during the first year post-transplantation (Biagini 2009; Okamoto, 2009; Gilles et al., 2017). Transfusion-transmitted

*Corresponding author. E-mail: iravanisaadi@sums.ac.ir; phone: +98 7136281528 .

Abbreviations: GvHD = graft-versus-host disease; HSCT = hematopoietic stem cell transplantation; $\mathrm{IL}=$ interleukin; TTV $=$ torque teno virus; TNF- $\alpha=$ tumor necrosis factor $\alpha$ virus or torque teno virus (TTV), a chronically persisting DNA virus, is a recently discovered infecting agent affecting human beings worldwide. It was isolated from the serum of a patient with post-transfusion hepatitis of unknown etiology. Generally, low-level of TTV viremia is detectable in up to $90 \%$ of healthy carriers (Gilles et al., 2017). However, TTV replication was known as an indicator of the impairment of the immune system in transplant recipients receiving immune suppression regiment and patients infected with HIV (Shang et al., 2000; Shibayama et al., 2001; Rajcani 2007; De Vlaminck et al., 2013).

Therefore, suppressing the immune system in order to combat organ transplant rejection, increases the chance of TTV viral replication and elevation of its blood load in 
these immunocompromised patients (Masouridi-Levrat et al., 2016).

It has been found that cytokines including TNF- $\alpha$, IL- 6 , IL-8 and IL-10 are involved in many adverse conditions initiated after HSCT, like sepsis, bacterial, viral or fungal infections, acute GVHD (aGVHD) and veno-occlusive disease (VOD) (Min et al., 2001; Döring et al., 2015). There are reports showing a relationship between the polymorphism in cytokine genes, e.g. IL-17, TNF- $\alpha$, and IL-10, and the outcome of viral infection like HBV infection (Höhler et al., 1998; Baghi et al., 2015; Azar et al., 2016; Ren et al., 2017). Little is known about the association between cytokine gene polymorphisms and viral infection post-HSCT (Lin et al., 2015). However, no report about the effect of cytokine gene polymorphism and susceptibility to TTV infection post-HSCT is available.

The current study aimed to evaluate the association between single-nucleotide polymorphisms (SNPs) located in the cytokine genes including IL-12 (-1188A/C), IL-17 (-197G/A), IL-10 (-1082G/A, -819C/T and -592C/A) and TNF- $\alpha(-308 \mathrm{G} / \mathrm{A})$ with TTV infection in patients post HSCT.

\section{Materials and Methods}

Patients' selection criteria. In this cross-sectional study, 72 post-hematopoietic stem cell transplanted patients were recruited from South of Iran who referred to our referral hospital between years 2012-2015. All of the patients received HSCT from related HLA-matched donors and subgrouped to aGvHD-experienced and not-experienced (non-aGvHD) HSCT patients. aGvHD was graded according to the classic Glucksberg-Seattle criteria and the International Bone Marrow Transplant Registry (Glucksberg et al., 1974). Out of all 72 transplanted patients, 29 had acute myeloid leukemia (AML), 10 had chronic myelogenous leukemia (CML), 20 had acute lymphocytic leukemia (ALL) and 13 had thalassemia.

Conditioning chemotherapy regimen included busulfan $16 \mathrm{mg} /$ $\mathrm{kg}$ or busulfex IV (80\% of oral dose) and cyclophosphamide $120-200 \mathrm{mg} / \mathrm{kg}$ in leukemia patients. GvHD prophylaxis consisted of cyclosporine and methotrexate. Prophylactic antibiotic, antifungal, and antiviral drugs were prescribed for all patients. All experiments were performed in accordance with the ethical standards of the Declaration of Helsinki. This study was approved by the Ethics Committee of Shiraz University of Medical Sciences (approval number 94-01-32-10603) and written informed consent was obtained from all patients.

Detection of TTV infection. The TTV infection was detected using the PCR-based method. Briefly, the TTV genomic DNA was extracted from blood using dinitrophenol (DNP) kit (Cinna Gen Inc., Tehran, Iran) according to manufacturer's instructions. The presence of TTV genomic DNA was analyzed in HSCT patients using an in-house semi nested-PCR protocol, as previously described (Shaheli M et al., 2015).

Screening for TNF- $\alpha$ and IL-10, IL-12 and IL-17 polymorphism using the PCR-RFLP method. Genomic DNA was extracted from the EDTA-treated Buffy coats using a QIAamp DNA mini kit (Qiagen, Germany) according to the manufacturer's instructions. The IL-12 (-1188A/C), IL-17 (-197G/A), IL-10 (-1082G/A, -819C/T and $-592 \mathrm{C} / \mathrm{A})$ polymorphisms were analyzed in studied patients using PCR-RFLP method, while TNF- $\alpha$ (-308 G/A) polymorphism was detected by ARMS method using two specific forward and reverse

Table 1. The primers, product sizes and PCR programs for the TNF- $\alpha$ and IL-10, IL-12 and IL-17 polymorphism

\begin{tabular}{|c|c|c|c|}
\hline \multicolumn{4}{|l|}{ PCR-RFLP method } \\
\hline Locus & Primers & Enzyme & Fragment length (bp) \\
\hline IL-17(rs227591-197 G/A) & $\begin{array}{l}\text { Forward: GCAGCTCTGCTCAGCTTCTAA } \\
\text { Reverse: TTCAGGGGTGACACCATTTT }\end{array}$ & BstENI & $\begin{array}{l}\text { AA: } 155 \text { GG: } 87+68 \\
\text { AG: } 155,87,68\end{array}$ \\
\hline IL-12(rs321227-1188A/C) & $\begin{array}{l}\text { Forward: CTGATCCAGGATGAAAATTTGG } \\
\text { Reverse: CCCATGGCAACTTGAGAGCTGG }\end{array}$ & TaqI & $\begin{array}{l}\text { AA:233bp } \\
\text { CC: } 165 b p+68 b p \\
\text { AC: } 233 b p+165 b p+68 b p\end{array}$ \\
\hline IL-10(rs1800896-1082G/A) & $\begin{array}{l}\text { Forward: CTCGCTGCAACCCAACTGGC } \\
\text { Reverse: TCTTACCTATCCCTACTTCC }\end{array}$ & MnlI & $\begin{array}{l}\text { GG:106,33bp } \\
\text { AA:139bp } \\
\text { AG:139,106,33bp } \\
\end{array}$ \\
\hline IL-10 (rs1800871-819 C/T) & $\begin{array}{l}\text { Forward: TCATTCTATGTGCTGGAGATGG } \\
\text { Reverse: TGGGGGAAGTGGGTAAGAGT }\end{array}$ & MaeIII & $\begin{array}{l}\text { TT:209bp } \\
\text { CC:125,84bp } \\
\text { TC:209,125,84bp }\end{array}$ \\
\hline IL-10 (rs1800872-592C/A) & $\begin{array}{l}\text { Forward: CCTAGGTCACAGTGACGTCG } \\
\text { Reverse: GGTGAGCACTACCTGACTAGC }\end{array}$ & Rsa & $\begin{array}{l}\text { AA:236,176bp } \\
\text { CC:412bp } \\
\text { AC:412,236,176bp } \\
\end{array}$ \\
\hline \multicolumn{4}{|l|}{ ARMS method } \\
\hline Locus & Primers & & \\
\hline TNF- $\alpha($ rs1800629;-308A/C) & $\begin{array}{l}\text { Forward: AAGAATCATTCAACCAGCGG } \\
\text { Reverse: ATAGGTTTTGAGGGGCATCA } \\
\text { Common: AAGAATCATTCAACCAGCGG }\end{array}$ & & \\
\hline
\end{tabular}


Table 2. Genotype and allele frequencies of the TNF and IL-10, IL-12 and IL-17 polymorphisms in TTV ${ }^{+}$and TTV infected allogeneic HSCT patients

\begin{tabular}{|c|c|c|c|c|c|c|}
\hline SNPs & Genotypes & $\mathrm{TTV}^{+} \mathrm{N}(\%)$ & TTV $^{-} \mathbf{N}(\%)$ & $p$-value & OR & $95 \%$ CI \\
\hline \multirow[t]{5}{*}{ IL-12 } & $\mathrm{AA}$ & $17(63)$ & $32(71.1)$ & 0.4 & 0.69 & $0.22-2.14$ \\
\hline & $\mathrm{CC}$ & $2(7.4)$ & $4(8.9)$ & 0.82 & 0.82 & $0.10-5.82$ \\
\hline & $\mathrm{AC}$ & $8(29.6)$ & $9(20)$ & 0.35 & 1.68 & $0.49-5.81$ \\
\hline & A allele & $42(77.7)$ & $73(81.1)$ & 0.62 & 0.82 & $0.33-2.03$ \\
\hline & C allele & $12(22.2)$ & $17(18.9)$ & & & \\
\hline \multirow[t]{5}{*}{ TNF- $\alpha$} & GG & $6(22.2)$ & $12(26.7)$ & 0.67 & 0.79 & $0.22-2.73$ \\
\hline & $\mathrm{AA}$ & $1(3.7)$ & $3(6.7)$ & 0.59 & 0.54 & $0.02-6.36$ \\
\hline & $\mathrm{AG}$ & $20(74.1)$ & $30(66.7)$ & 0.50 & 1.43 & $0.44-4.72$ \\
\hline & A allele & $22(40.7)$ & $54(60.0)$ & $0.025^{*}$ & 0.46 & $0.22-0.96$ \\
\hline & G allele & 32(59.3.) & $36(40.0)$ & & & \\
\hline \multirow[t]{5}{*}{ IL-17 } & AA & $15(55.6)$ & $30(66.7)$ & 0.34 & 0.63 & $0.21-1.86$ \\
\hline & GG & $1(3.7)$ & $4(8.9)$ & 0.24 & 0.28 & $0.01-2.93$ \\
\hline & $\mathrm{AG}$ & 11(40.7) & $11(24.4)$ & 0.14 & 2.13 & $0.68-6.73$ \\
\hline & A allele & $41(75.9)$ & $71(78.8)$ & 0.67 & 0.84 & $0.35-2.03$ \\
\hline & G allele & $13(24.1)$ & $19(21.2)$ & & & \\
\hline \multirow[t]{5}{*}{ IL-10-592 } & $\mathrm{AA}$ & $2(7.4)$ & $5(11.1)$ & 0.60 & 0.64 & $0-08-4.19$ \\
\hline & CC & $14(51.9)$ & $31(68.9)$ & 0.14 & 0.49 & $0.16-1.45$ \\
\hline & $\mathrm{AC}$ & 11(40.7) & $9(20)$ & $0.057^{\star}$ & 2.75 & $0.84-9.10$ \\
\hline & A allele & $15(27.7)$ & $19(21.1)$ & 0.36 & 1.44 & $0.61-3.37$ \\
\hline & C allele & $39(72.3)$ & $71(78.9)$ & & & \\
\hline \multirow[t]{5}{*}{ IL-10-1082 } & AA & $17(63)$ & $26(57.8)$ & 0.66 & 1.24 & $0.42-3.72$ \\
\hline & GG & $1(3.7)$ & $4(8.9)$ & 0.40 & 0.39 & $0.02-4.13$ \\
\hline & AG & $9(33.3)$ & $15(33.3)$ & 1 & 1 & $0.32-3.08$ \\
\hline & A allele & $43(79.6)$ & $67(74.4)$ & 0.47 & 1.34 & $0.55-3.28$ \\
\hline & G allele & $11(20.4)$ & $23(25.6)$ & & & \\
\hline \multirow[t]{5}{*}{ IL-10-819 } & $\mathrm{CC}$ & $14(51.9)$ & $25(55.6)$ & 0.76 & 0.86 & $0.30-2.50$ \\
\hline & $\mathrm{TT}$ & $5(18.5)$ & $3(6.7)$ & 0.12 & 0.12 & $0.58-8.89$ \\
\hline & TC & $8(29.6)$ & $17(37.8)$ & 0.48 & 0.48 & $0.22-2.16$ \\
\hline & $\mathrm{C}$ allele & $36(66.7)$ & $67(23)$ & 0.31 & 0.31 & $0.31-1.53$ \\
\hline & $\mathrm{T}$ allele & $18(33.3)$ & & & & \\
\hline
\end{tabular}

$\mathrm{N}=$ absolute number; $\mathrm{CI}=$ confidence interval; $\mathrm{OR}=$ odds ratio. ${ }^{*}$ Considered significant with $p$-value threshold of 0.05 . In genotypes, each $p$ value is the result of comparing corresponding row with the sum of other rows.

primers along with a common primer. The primer sequences for all genes are presented in Table 1 .

Statistical analysis. Statistical evaluation was carried out using the version 18 of SPSS software. The frequencies of alleles/genotypes and the relationships between SNPs and active TTV infection were analyzed in HSCT patients by chi-square test and Fisher's exact test. The odds ratios (ORs) and 95\% confidence intervals (95\% CIs) for relative risks were calculated. A $p$-value $<0.05$ was considered statistically significant.

\section{Results}

\section{Patients' characteristics}

In this study, 72 post HSCT patients including 32 (44.4\%) male and 40 (55.6\%) female were genotyped. The mean age of patients was $24.6 \pm 0.1$ (range between 20-30 years old). $27(37.5 \%)$ of patients had aGVHD including 8 (29.6\%) patients with grade 1, $10(37.03 \%)$ grade $2,6(22.2 \%)$ grade 3 and $3(11.1 \%)$ grade 4 , while $45(62.5 \%)$ experienced no aGVHD. Among all patients, 27 (37.5\%) were infected with TTV $\left(\mathrm{TTV}^{+}\right)$and $45(62.5 \%)$ had no TTV infection (TTV*) post HSCT.

Analysis of the IL-10, IL-12, IL-17 and TNF- $\alpha$ polymorphisms and TTV infection in HSCT patients

The genotypes and allele frequency of the IL-10, IL-12, IL-17 and TNF- $\alpha$ polymorphisms were compared in patients according to the TTV infection status. Our results showed that the distribution of all genotypes, a s well as alleles of IL-12 and IL-17 polymorphisms, was not significantly different between $\mathrm{TTV}^{+}$and TTV ${ }^{-}$patients (Table 2). However, the frequency of the A allele of TNF- $\alpha$ significantly increased in $\mathrm{TTV}^{-}$patients compared to $\mathrm{TTV}^{+}$patients $(p=0.025$, $\mathrm{OR}=0.4695 \% \mathrm{CI}=0.22-0.96$; Table 3 ). Also, the AC genotype of the IL-10 -592 had significantly higher frequency in 
Table 3. Genotype and allele frequencies of the TNF and IL-10, IL-12, IL-17 polymorphisms in TTV ${ }^{+}$and TTV patients experiencing aGVHD

\begin{tabular}{|c|c|c|c|c|c|c|}
\hline SNPs & Genotypes & $\begin{array}{c}\text { aGVHD+ } \text { TTV }^{+} \\
\text {N(\%) }\end{array}$ & $\begin{array}{c}\text { aGVHD+ TTV } \\
\text { N(\%) }\end{array}$ & $p$-value & OR & $95 \%$ CI \\
\hline \multirow[t]{5}{*}{ IL-12 } & AA & $7(70)$ & $10(58.8)$ & 0.561 & 1.63 & $0.24-11.88$ \\
\hline & $\mathrm{CC}$ & $1(10 \%)$ & $1(5.9)$ & 0.693 & 1.78 & $0.00-76.13$ \\
\hline & AC & $2(20 \%)$ & $6(35.3)$ & 0.400 & 0.46 & $0.05-3.74$ \\
\hline & A allele & $17(33.3)$ & $26(76.4)$ & 0.695 & 1.31 & $0.29-6.21$ \\
\hline & C allele & $44(66.7)$ & $8(23.6)$ & & & \\
\hline \multirow[t]{5}{*}{ TNF- $\alpha$} & GG & $2(20)$ & $3(17.6)$ & 0.879 & 1.17 & $0.11-11.90$ \\
\hline & $\mathrm{AA}$ & $1(10)$ & $2(11.8)$ & 0.887 & 0.83 & $0.03-14.94$ \\
\hline & $\mathrm{AG}$ & $7(70)$ & $12(70.6)$ & 0.974 & 0.97 & $0.13-7.38$ \\
\hline & A allele & $9(45.0)$ & $16(47.0)$ & 0.883 & 0.92 & $0.26-3.21$ \\
\hline & G allele & $11(55.0)$ & $18(53.0)$ & & & \\
\hline \multirow[t]{5}{*}{ IL-17 } & AA & $2(20)$ & $11(64.7)$ & $0.024^{*}$ & 0.14 & 0.01-1.09 \\
\hline & GG & $1(10)$ & $1(5.9)$ & 0.693 & 1.78 & $0.00-76.13$ \\
\hline & $\mathrm{AG}$ & $7(70)$ & $5(29.4)$ & $0.040^{*}$ & 5.60 & $0.79-45.92$ \\
\hline & A allele & $11(55)$ & $27(79.4)$ & $0.057^{\star}$ & 0.32 & $0.08-1.24$ \\
\hline & G allele & $9(45)$ & $7(20.6)$ & & & \\
\hline \multirow[t]{5}{*}{ IL-10-592 } & $\mathrm{CC}$ & $7(70)$ & $12(70.6)$ & 0.974 & 0.97 & $0-13-7.38$ \\
\hline & AC & $3(30)$ & $3(17.6)$ & 0.455 & 2 & $0.23-17.95$ \\
\hline & $\mathrm{AA}$ & 0.00 & $2(11.8)$ & 0.259 & 0.00 & $0.00-7.62$ \\
\hline & C allele & $17(85)$ & $27(79.4)$ & 0.609 & 1.47 & $0.28-8.42$ \\
\hline & A allele & $3(15)$ & $7(20.6)$ & & & \\
\hline \multirow[t]{5}{*}{ IL-10-1082 } & AA & $8(80)$ & $6(52.9)$ & 0.159 & 3.56 & $0.45-3.69$ \\
\hline & GG & $2(20)$ & $5(29.4)$ & 0.589 & 0.60 & $0.06-5.10$ \\
\hline & AG & 0.00 & $3(17.6)$ & 0.158 & 0.00 & $0.00-4.04$ \\
\hline & A allele & $18(90.0)$ & $23(67.6)$ & 0.063 & 4.30 & $0.74-32.28$ \\
\hline & G allele & $2(10.0)$ & $11(33.4)$ & & & \\
\hline \multirow[t]{5}{*}{ IL-10-819 } & $\mathrm{CC}$ & $7(70)$ & $10(58.8)$ & 0.561 & 1.63 & $0.24-11.88$ \\
\hline & $\mathrm{TT}$ & $2(20)$ & $1(5.9)$ & 0.259 & 4 & $0.22-132.49$ \\
\hline & TC & $1(10)$ & $6(35.3)$ & 0.147 & 0.20 & $0.01-2.41$ \\
\hline & $\mathrm{C}$ allele & $15(75)$ & $26(76.4)$ & 0.902 & 0.92 & $0.22-4.02$ \\
\hline & $\mathrm{T}$ allele & $5(25)$ & $8(23.6)$ & & & \\
\hline
\end{tabular}

$\mathrm{N}=$ absolute number; $\mathrm{CI}=$ confidence interval; $\mathrm{OR}=$ odds ratio. ${ }^{*}$ Considered significant with $p$ value threshold of 0.05 . In genotypes, each $p$-value is the result of comparing corresponding row with the sum of other rows.

$\mathrm{TTV}^{+}$patients than $\mathrm{TTV}^{-}$ones $(p=0.057, \mathrm{OR}=2.75,95 \%$ $\mathrm{CI}=0.84-9.10$; Table 2).

Association of the IL-10, IL-12, IL-17 and TNF- $\alpha$ polymorphisms with TTV infection in aGvHD-experienced patients

Among patients who experienced aGvHD, the AA genotype and A allele of the IL-17 has significantly higher frequency in $\mathrm{TTV}^{-}$patients compared to $\mathrm{TTV}^{+}$patients $(p=0.024, \mathrm{OR}=0.14,95 \% \mathrm{CI}=0.01-1.09 ; p=0.057$, $\mathrm{OR}=0.32,95 \% \mathrm{CI}=0.08-1.24$, respectively; Table 3 ), while the frequency of the AG genotype of the IL-17 was significantly higher in $\mathrm{TTV}^{+}$patients compared to $\mathrm{TTV}^{-}$patients $(p=0.04, \mathrm{OR}=5.60,95 \% \mathrm{CI}=0.79-45.92$, Table 3$)$. Of all TTV+ patients, the GG genotype of the IL-17 had a significantly higher frequency in HSCT patients who experienced low grade (grade I+II) disease compared to high grade (grade III and IV) disease $(p=0.056$; Table 4$)$.
In addition, among $\mathrm{TTV}^{+}$patients, the AA genotype of the TNF- $\alpha$ had a significantly higher frequency in HSCT patients who experienced low grade (grade I+II) disease compared to high grade (grade III and IV) disease ( $p=0.056$; Table 4$)$.

There was no significant difference in genotype and allele frequency of both IL-12 and IL-10 polymorphisms (-592, -1082 and -819) in aGvHD-experienced patients regarding TTV infection status and also in TTV-infected patients among HSCT patients with low grade (grade I+II) disease compared to high grade (grade III and IV) disease ( $p>0.05$, Table 3 and Table 4).

Analysis of the IL-12, IL-17 and IL-10 polymorphisms according to gender

When the HSCT patients were classified according to their gender, it was observed that among $\mathrm{TTV}^{+}$patients, the frequency of AA genotype and the A allele of the IL-10 -1082 was significantly higher in $\mathrm{TTV}^{+}$male patients compared 
Table 4. Genotype and allele frequencies of the TNF and IL-10, IL-12, IL-17 polymorphisms in TTV+ patients experiencing low grade (grade I+II) compared to high grade (grade III and IV) aGVHD

\begin{tabular}{|c|c|c|c|c|c|c|}
\hline SNPs & Genotypes & $\begin{array}{c}\text { TTV+ low grade } \\
\text { (grade I+II) } \\
\text { N(\%) }\end{array}$ & $\begin{array}{c}\text { TTV+ high grade } \\
\text { (grade III and IV) } \\
\text { N(\%) }\end{array}$ & $p$-value & OR & 95\% CI \\
\hline \multirow[t]{5}{*}{ IL-12 } & AA & $4(66.7)$ & 13 (61.9) & 0.83 & 1.23 & $0.14-12.69$ \\
\hline & $\mathrm{CC}$ & $0.00(0.00)$ & $2(9.5)$ & 0.432 & 0.00 & $0.00-17.53$ \\
\hline & $\mathrm{AC}$ & $2(33.3)$ & $6(28.6)$ & 0.821 & 1.25 & $0.12-12.13$ \\
\hline & A allele & $10(83.3)$ & $32(76.1)$ & 0.599 & 1.56 & $0.25-12.32$ \\
\hline & $\mathrm{C}$ allele & $2(16.7)$ & $10(33.9)$ & & & \\
\hline \multirow[t]{5}{*}{ TNF- $\alpha$} & $\mathrm{AA}$ & $1(16.7)$ & $0.00(0.00)$ & $0.056^{*}$ & Undefined & $0.08-1$ \\
\hline & GG & $0.00(0.00)$ & $6(28.6)$ & 0.137 & 0.00 & $0.00-3.33$ \\
\hline & AG & $5(83.3)$ & $15(7.4)$ & 0.557 & 2 & $0.15-55.39$ \\
\hline & A allele & $7(58.3)$ & $15(35.7)$ & 0.159 & 2.52 & $0.58-11.38$ \\
\hline & G allele & $5(41.7)$ & $27(64.3)$ & & & \\
\hline \multirow[t]{5}{*}{ IL-17 } & $\mathrm{AA}$ & $2(33.3)$ & $13(61.9)$ & 0.214 & 0.31 & $0.03-2.74$ \\
\hline & GG & $1(16.7)$ & $0.00(0.00)$ & $0.056^{*}$ & Undefined & Undefined \\
\hline & $\mathrm{AG}$ & $3(50)$ & $8(38.1)$ & 0.600 & 1.63 & $0.19-14.20$ \\
\hline & A allele & $7(58.3)$ & $24(75)$ & 0.280 & 0.47 & $0.09-2.33$ \\
\hline & G allele & $5(41.7)$ & $8(25)$ & & & \\
\hline \multirow[t]{5}{*}{ IL-10-592 } & $\mathrm{CC}$ & $4(66.7)$ & $10(47.6)$ & 0.41 & 2.20 & $0-25-22.56$ \\
\hline & $\mathrm{AA}$ & 0 & $2(9.5)$ & 0.432 & 0.00 & $0.00-17.53$ \\
\hline & $\mathrm{AC}$ & $2(33.3)$ & $9(42.9)$ & 0.675 & 0.67 & $0.07-5.96$ \\
\hline & A allele & $2(16.6)$ & $13(30.9)$ & 0.329 & 0.45 & $0.06-2.70$ \\
\hline & C allele & $10(83.4)$ & $29(69.1)$ & & & \\
\hline \multirow[t]{5}{*}{ IL10-1082 } & AA & $5(83.3)$ & $12(57.1)$ & 0.241 & 3.75 & $0.31-100.94$ \\
\hline & GG & 0 & $1(4.8)$ & 0.585 & 0.00 & $0.00-70.88$ \\
\hline & $\mathrm{AG}$ & $1(16.7)$ & $8(38.1)$ & 0.326 & 0.32 & $0.01-4.04$ \\
\hline & A allele & 11(91.6) & $32(76.1)$ & 0.240 & 3.44 & $0.37-79.96$ \\
\hline & G allele & $1(8.4)$ & $10(23.9)$ & & & \\
\hline \multirow[t]{5}{*}{ IL-10-819 } & $\mathrm{CC}$ & $4(66.7)$ & $10(47.6)$ & 0.41 & 2.20 & $0.25-22.56$ \\
\hline & TT & $1(16.7)$ & 4(19) & 0.894 & 0.85 & $0.00-12.63$ \\
\hline & TC & $1(16.7)$ & $7(33.3)$ & 0.430 & 0.40 & $0.01-5.09$ \\
\hline & $\mathrm{T}$ allele & $3(25)$ & $15(35.7)$ & 0.487 & 0.60 & $0.11-3.01$ \\
\hline & C allele & $9(75)$ & $27(64.3)$ & & & \\
\hline
\end{tabular}

$\mathrm{N}=$ absolute number; $\mathrm{CI}=$ confidence interval; $\mathrm{OR}=$ odds ratio. ${ }^{*}$ Considered significant with $p$-value threshold of 0.05 . In genotypes, each $p$-value is the result of comparing corresponding row with the sum of other rows.

to female ones $(p=0.017, \mathrm{OR}=7.58,95 \% \mathrm{CI}=1.01-68.44$; $p=0.015, \mathrm{OR}=5.52,95 \% \mathrm{CI}=1.08-31.66$, respectively; Table 5), whereas, the AG genotype of the IL-10 -1082 had significantly higher frequency in female compared to male ones $(p=0.052$, OR $=0.19,95 \% \mathrm{CI}=0.02-1.41$; Table 5$)$.

\section{Discussion}

Administration of immunosuppressive drugs is routinely used to prevent GvHD, the most common complication occurring post allogeneic HSCT, which is consequently associated with the occurrence of viral infection, because of the down-regulation of the host immune responses. Despite that, the reason that why some HSCT recipients rapidly develop severe infections while other (despite using immunosuppressive drugs) do not, is not clearly defined. There is increasing evidence suggesting that such differences may be somehow linked to the polymorphisms in genes encoding cytokines (Wójtowicz et al., 2016). The cytokines represent the major factor in the regulation of the immune response to infectious agents especially viral infections, the most common complication observed after HSCT. TTV viremia is one of the hallmarks of viral infection observed post-HSCT, because the viral load increases greatly after administration of immunosuppressive drugs (Masouridi-Levrat et al., 2016). Since the immune system plays the most important role in eliminating viral infection, level of cytokines and their variation may contribute to the control of the TTV virus levels by the immune system.

In this study, the association between single-nucleotide polymorphisms (SNPs) in the cytokine genes including IL-12 (-1188A/C), IL-17 (-197G/A), IL-10 (-1082G/A, -819C/T and $-592 \mathrm{C} / \mathrm{A})$ and TNF- $\alpha(-308 \mathrm{G} / \mathrm{A})$ and TTV infection was evaluated in patients with HSCT. While our results did not show any association between IL-17, IL-12 and IL-10 
Table 5. Genotype frequencies of the TNF and IL-10, IL-12 and IL-17 polymorphisms in male and female TTV ${ }^{+}$allogeneic HSCT patients

\begin{tabular}{|c|c|c|c|c|c|c|}
\hline SNPs & Genotypes & Male N(\%) & Female N(\%) & $p$-value & OR & $95 \% \mathrm{CI}$ \\
\hline \multirow[t]{5}{*}{ IL-12 } & AA & $11(68.8)$ & $6(54.5)$ & 0.452 & 1.83 & $0.29-12.20$ \\
\hline & $\mathrm{CC}$ & $1(6.3)$ & $1(9.1)$ & 0.781 & 0.67 & $0.02-28.21$ \\
\hline & $\mathrm{AC}$ & $40(25)$ & $4(36.4)$ & 0.525 & 0.58 & $0.08-4.12$ \\
\hline & A allele & $26(81.2)$ & $16(72.7)$ & 0.459 & 1.63 & $0.38-7.09$ \\
\hline & C allele & $6(18.8)$ & $6(27.3)$ & & & \\
\hline \multirow[t]{5}{*}{ TNF- $\alpha$} & GG & $4(25)$ & $2(18.2)$ & 0.675 & 1.50 & $0.17-15.36$ \\
\hline & AA & $1(6.3)$ & $0.00(0.00)$ & 0.398 & Undefined & Undefined \\
\hline & AG & $11(68.8)$ & $9(81.8)$ & 0.446 & 0.49 & $0.05-4.10$ \\
\hline & A allele & $13(30.9)$ & $9(40.9)$ & 0.425 & 0.65 & $0.19-2.16$ \\
\hline & G allele & $29(69.1)$ & $13(59.1)$ & & & \\
\hline \multirow[t]{5}{*}{ IL-17 } & AA & $7(43.8)$ & $8(72.7)$ & 0.136 & 0.29 & $0.04-1.96$ \\
\hline & GG & $1(6.3)$ & $0.00(0.00)$ & 0.398 & Undefined & Undefined \\
\hline & AG & $3(50)$ & $3(27.3)$ & 0.237 & 2.67 & $0.40-19.41$ \\
\hline & A allele & $22(68.7)$ & $19(86.3)$ & 0.136 & 0.35 & $0.06-1.68$ \\
\hline & G allele & $10(31.3)$ & $3(13.7)$ & & & \\
\hline \multirow[t]{5}{*}{ IL-10-592 } & CC & $9(56.3)$ & $5(45.5)$ & 0.581 & 1.54 & $0.25-9.64$ \\
\hline & AA & $2(12.5)$ & 0.00 & 0.222 & Undefined & Undefined \\
\hline & $\mathrm{AC}$ & $5(31.3)$ & $6(54.5)$ & 0.226 & 0.38 & $0.06-2.40$ \\
\hline & A allele & $9(28.1)$ & $6(27.2)$ & 0.945 & 1.04 & $0.27-4.16$ \\
\hline & C allele & $23(71.9)$ & $16(72.8)$ & & & \\
\hline \multirow[t]{5}{*}{ IL-10-1082 } & AA & $13(83.3)$ & $4(36.4)$ & $0.017^{*}$ & 7.58 & $1.01-68.44$ \\
\hline & GG & $0.00(0.00)$ & $1(9.1)$ & 0.219 & 0.00 & $0.00-12.49$ \\
\hline & AG & $3(18.8)$ & $6(54.5)$ & $0.052^{*}$ & 0.19 & $0.02-1.41$ \\
\hline & A allele & $29(90.6)$ & $14(63.6)$ & $0.015^{*}$ & 5.52 & $1.08-31.66$ \\
\hline & G allele & $3(9.4)$ & $8(36.4)$ & & & \\
\hline \multirow[t]{5}{*}{ IL10-819 } & CC & $9(56.3)$ & $5(45.5)$ & 0.581 & 1.54 & $0.25-9.64$ \\
\hline & $\mathrm{TT}$ & $3(18.8)$ & $2(18.2)$ & 0.97 & 1.04 & $0.10-11.43$ \\
\hline & $\mathrm{TC}$ & $4(25)$ & $4(36.4)$ & 0.525 & 0.58 & $0.08-4.12$ \\
\hline & T allele & $10(31.3)$ & $8(36.4)$ & 0.695 & 0.80 & $0.22-2.91$ \\
\hline & C allele & $22(68.7)$ & $14(63.6)$ & & & \\
\hline
\end{tabular}

$\mathrm{N}=$ absolute number; $\mathrm{CI}=$ confidence interval; $\mathrm{OR}=$ odds ratio. ${ }^{*}$ Considered significant with $p$-value threshold of 0.05 . In genotypes, each $p$-value is the result of comparing corresponding row with the sum of other rows.

$(-1082 \mathrm{G} / \mathrm{A}$ and $-819 \mathrm{C} / \mathrm{T})$ polymorphisms and TTV infection status, heterozygote genotype of the IL-10 (-592C/A) gene had direct correlation with TTV infection and A allele of TNF- $\alpha$ (-308G/A) showed to be protective against TTV infection.

There are reports showing a relationship between the polymorphism in cytokine genes and the outcome of viral infection like HBV; in one study by Hohler et al. (1998) a positive association between TNF- $\alpha$ polymorphism at position -238 and development of chronic HBV infection and the progression of the infection has been reported. Panigrahi et al. (2014) reported an association between the polymorphism in the promoter region of the TNF- $\alpha$ gene at position -238 and -863 with the outcome $\mathrm{HBV}$ infection and disease progression. Also, Ren et al. (2017) showed an association between IL-17A rs2275913 and IL-17F rs763780 polymorphisms with HBV infection in the Han Chinese population. They concluded that the presence of the GG genotype and the G allele at rs2275913, and the TT genotype and the $\mathrm{T}$ allele at rs763780 might increase the risk of HBV infection (Ren et al., 2017). Consistent with our results, Talaat et al. (2012) reported that in the case of TNF- $\alpha-308$ polymorphism, the frequency of the A allele was significantly higher in healthy controls than in HCV-infected patients. In a study by Azar et al. (2016) in North of Iran, it was demonstrated that TNF- $\alpha-308$ G/G polymorphism was associated with HBV resistance, whereas TNF- $\alpha-308 \mathrm{~A}$ (A/A or $A / G)$ polymorphism appeared to associated with chronic $\mathrm{HBV}$ infection. In line with our findings, Ghaleh Baghi et al. (2015) showed that the C/A genotype at position -592, C/T genotype at position -819, and GCC/ATA haplotype of the IL-10 gene promoter were significantly more common in the patients with cirrhosis caused post-HBV infection. However, little is known about the association of cytokine gene polymorphisms and viral infection post HSCT. Lin et al. (2015) studied the cytokine polymorphisms and EBV infection after allogeneic HSCT and showed that patients with EBV infection/reactivation had higher frequencies of donor IL-1 $\beta-511$ TT genotype, donor IL-4 -590 TT genotype and recipient TNF- $\alpha-308$ GG genotype than in 
$\mathrm{EBV}^{-}$patients, while the frequencies of donor IL- $1 \beta-511$ CC genotype, donor IL-1RN +11100 TT genotype, donor IL-2 -330 TT genotype, donor IL-4 -590 CC genotype and recipient TNF- $\alpha-308$ GA genotype in $\mathrm{EBV}^{+}$patients were lower than in $\mathrm{EBV}^{-}$patients.

Another finding of our study was that in patients who experienced aGVHD, the AA genotype and the A allele of IL-17 (-197 G/A) were significantly higher in TTV- patients compared to $\mathrm{TTV}^{+}$ones. Accordingly, it seems that the AA genotype and A allele of IL-17 -197 G/A polymorphism may be associated with resistance to TTV infection in HSCT patients experiencing aGvHD. It was also observed that among $\mathrm{TTV}^{+}$patients, the GG genotype of IL-17 and AA genotype of TNF- $\alpha$ were significantly increased in HSCT patients with low grade (grade I+II) disease compared to high grade (grade III and IV) disease. Moreover, among TTV ${ }^{+}$patients, the frequency of AA genotype and the A allele of the IL-10 -1082 was more frequent in $\mathrm{TTV}^{+}$male patients whereas, the AG genotype of the IL-10 -1082 had a significantly higher frequency in female ones.

IL-10 is a key pleiotropic immunoregulatory cytokine secreted largely by macrophages, and also by $\mathrm{T}$ helper 1 (Th1) and Th2 lymphocytes, dendritic cells, cytotoxic T cells, B lymphocytes, monocytes and mast cells as well as human carcinoma cell lines (Gastl et al., 1993; Trifunović et al., 2015). There are three single nucleotide polymorphisms (SNPs) -1082(G/A), -819(C/T) and -592(C/A) at promoter region, which form three predominant haplotypes (GCC, ACC, ATA) (Trifunović et al., 2015). It has been reported that the -592 A allele, the -1082 A allele as well as the ATA haplotype are associated with lower IL-10 expression level (Lowe et al., 2003). Therefore, the -592 A allele can be regarded as a low-producer allele of the $I L-10$ gene. It is proposed that during viral infections, the antiviral and inflammatory signals stimulate activated T cells to produce IL-10, which has negative feedback regulatory mechanism that limits extreme inflammation (Rojas et al., 2017). In addition, in viral infection, IL-10 regulates B cell survival and differentiation as well as B cell effector function by stimulating Ig class switching and plasma cell differentiation at the expense of B memory cells (Moore et al., 2001). IL-10 could also play a role in the development of anti-viral CD8+ memory T cells (Rojas et al., 2017).

Tumor necrosis factor- $\alpha$ is a pro-inflammatory cytokine with an important role in the pathogenesis of several diseases and is thought to be involved in the regulation of many important cellular processes such as proliferation, differentiation, growth, and the immune response (Hayashi et al., 2013). It is produced by various cell types including macrophages, monocytes, neutrophils, T cells, and NK-cells. Several polymorphisms have been identified in the TNF- $\alpha$ promoter region at the positions $-1031(\mathrm{~T} / \mathrm{C}),-863(\mathrm{C} / \mathrm{A})$, -857 (C/A), -851 (C/T), -419 (G/C), -376 (G/A), -308 (G/A),
-238 (G/A), -162 (G/A), and -49 (G/A) (Elahi et al., 2009). Among these variants, a polymorphism that directly affects TNF- $\alpha$ expression is located at nucleotide position -308 (-308 $\mathrm{G} \rightarrow \mathrm{A}$ ) (Elahi et al., 2009). It has been shown that substitution of $\mathrm{G}$ allele (TNFA1 allele) with A allele (TNFA2 allele) of -308 polymorphism at the promoter region of the TNF- $\alpha$ gene is associated with elevated TNF- $\alpha$ levels and disease susceptibilities (Elahi et al., 2009).

There are several studies about the important role of TNF- $\alpha$ in immunity to viral infection like HBV, in which TNF acts as a key cytokine in virus eradication (Tzeng et al., 2014). In this regard, production of TNF-a has been associated with the increased expression of MHC class I molecules, which is associated with enhanced CD8+ T cell response to $\mathrm{HBV}$, and subsequently more effective destruction of HBV-infected hepatocytes (Hussain et al., 1994; Tzeng et al., 2014). It has also been demonstrated that depletion of TNF- $\alpha$ by treatment with TNF- $\alpha$ blockers (which is currently used to treat inflammatory diseases like rheumatoid arthritis and other inflammatory diseases) may facilitate the risk of or reactivation of viral infection (Kim et al., 2010; Pérez-Alvarez et al., 2011).

\section{Conclusion}

This is a first report describing that genetic variation of the IL-10 (-592C/A) and TNF- $\alpha$ (-308G/A) genes might be associated with susceptibility to TTV infection post-HSCT. Also, IL-17 (-197 G/A) may be contributed to TTV infection in HSCT patients experiencing GvHD. Therefore, it seems that cytokine polymorphism can be used as an indicator of post-transplant complications like TTV infection. In this regard, polymorphism in the other pro- and anti-inflammatory cytokines and also a correlation with their serum levels might be useful.

Acknowledgment. This study was supported by the Shiraz University of Medical Sciences.

\section{References}

Azar SS, Mansoori M, Attar M, Shahbazi M (2016): Tumor necrosis factor alpha $308 \mathrm{G} / \mathrm{A}$ single nucleotide polymorphism and susceptibility to hepatocellular carcinoma via hepatitis B infection. Asian Pac. J. Cancer Prev. 17, 3381-3384.

Baghi SG, Alavian SM, Mehrnoush L, Salimi S (2015): Impact of the IL-10 Promoter Gene Polymorphisms in the Severity of Chronic Hepatitis B Infection. Hepatitis monthly 15, e28287. https://doi.org/10.5812/hepatmon.28287v2

Biagini P (2009): Classification of TTV and Related Viruses (Anelloviruses). Curr. Top. Microbiol. Immunol. 331, 21-33. https://doi.org/10.1007/978-3-540-70972-5_2 
De Vlaminck I, Khush KK, Strehl C, Kohli B, Luikart H, Neff NF, Okamoto J, Snyder TM, Cornfield DN, Nicolls MR (2013): Temporal response of the human virome to immunosuppression and antiviral therapy. Cell 155, 1178-1187. https://doi.org/10.1016/j.cell.2013.10.034

Döring M, Stanchi K MC, Mezger M, Erbacher A, Feucht J, Pfeiffer M, Lang P, Handgretinger R, Müller I (2015): Cytokine serum levels during post-transplant adverse events in 61 pediatric patients after hematopoietic stem cell transplantation. BMC Cancer 15, 607. https://doi.org/10.1186/ $\underline{\text { s12885-015-1616-Z }}$

Elahi MM, Asotra K, Matata BM, Mastana SS (2009): Tumor necrosis factor alpha- 308 gene locus promoter polymorphism: an analysis of association with health and disease. Biochim. Biophys. Acta 1792, 163-172. https:// doi.org/10.1016/j.bbadis.2009.01.007

Gastl GA, Abrams JS, Nanus DM, Oosterkamp R, Silver J, Liu F, Chen M, Albino AP, Bander NH (1993): Interleukin-10 production by human carcinoma cell lines and its relationship to interleukin-6 expression. Int. J. Cancer 55, 96-101. https://doi.org/10.1002/ijc.2910550118

Gilles R, Herling M, Holtick U, Heger E, Awerkiew S, Fish I, Höller K, Sierra S, Knops E, Kaiser R (2017): Dynamics of Torque Teno virus viremia could predict risk of complications after allogeneic hematopoietic stem cell transplantation. Med. Microbiol. Immunol. 206, 355-362. https://doi. org/10.1007/s00430-017-0511-4

Glucksberg H, Storb R, Fefer A, Buckner CD, Neiman PE, Clift RA, Lerner KG, Thomas ED (1974): Clinical manifestations of graft-versus-host disease in human recipients of marrow from HL-A-matched sibling donors. Transplantation 18, 295-304. https://doi.org/10.1097/00007890-197410000$\underline{00001}$

Hayashi K, Piras V, Tabata S, Tomita M, Selvarajoo K (2013): A systems biology approach to suppress TNF-induced proinflammatory gene expressions. Cell Commun. Signal. 11, 84. https://doi.org/10.1186/1478-811X-11-84

Höhler T, Kruger A, Gerken G, Schneider PM, zum Büschenfelde KHM, Rittner C (1998): Tumor necrosis factor alpha promoter polymorphism at position-238 is associated with chronic active hepatitis $\mathrm{C}$ infection. J. Med. Virol. 54, 173-177. https://doi.org/10.1002/(SICI)10969071(199803)54:3<173::AID-JMV5>3.0.CO;2-2

Hussain M, Lau J, Williams R, Vergani D (1994): Hepatic expression of tumour necrosis factor-alpha in chronic hepatitis B virus infection. J. Clin. Pathol. 47, 1112-1115. https:// doi.org/10.1136/jcp.47.12.1112

Kim SY, Solomon DH (2010): Tumor necrosis factor blockade and the risk of viral infection. Nat. Rev. Rheumatol. 6, 165-174. https://doi.org/10.1038/nrrheum.2009.279

Lin R, Fan Z, Zhao K, Jiang Q, Sun J, Liu Q (2015): Cytokine Gene Polymorphisms and Epstein-Barr Virus Infection after Allogeneic Hematopoietic Stem Cell Transplantation. Blood 126, 3125.

Lowe PR, Galley HF, Abdel-Fattah A, Webster NR (2003): Influence of interleukin-10 polymorphisms on interleukin-10 expression and survival in critically ill patients. Crit.
Care Med. 31, 34-38. https://doi.org/10.1097/00003246200301000-00005

Masouridi-Levrat S, Pradier A, Simonetta F, Kaiser L, Chalandon Y, Roosnek E (2016): Torque teno virus in patients undergoing allogeneic hematopoietic stem cell transplantation for hematological malignancies. Bone Marrow Transplant. 51, 440-442. https://doi.org/10.1038/bmt.2015.262

Min C, Lee W, Min D, Lee D, Kim Y, Park Y, Kim H, Lee S, Kim D, Lee J (2001): The kinetics of circulating cytokines including IL-6, TNF- $\alpha$, IL-8 and IL-10 following allogeneic hematopoietic stem cell transplantation. Bone Marrow Transplant. 28, 935-940. https://doi.org/10.1038/ sj.bmt. 1703258

Moore KW, de Waal Malefyt R, Coffman RL, O'Garra A (2001): Interleukin-10 and the interleukin-10 receptor. Annu. Rev. Immunol. 19, 683-765. https://doi.org/10.1146/ annurev.immunol.19.1.683

Okamoto H (2009): History of discoveries and pathogenicity of TT viruses. TT Viruses. Springer, 1-20. https://doi. org/10.1007/978-3-540-70972-5 1

Panigrahi R, Sarkar N, Biswas A, Pal A, Saha D, Singh S P, Panigrahi MK, Bandopadhyay M, Chakrabarti S, Chakravarty R (2014): Association of TNF-a promoter polymorphism with HBV associated disease outcome among HBV infected patients from Orissa, southern part of East India. J. Clin. Exp. Hepatol. 4, 202-208. https://doi.org/10.1016/j. jceh.2014.08.002

Pérez-Alvarez R, Díaz-Lagares C, García-Hernández F, LopezRoses L, Brito-Zerón P, Pérez-de-Lis M, Retamozo S, Bové A, Bosch X, Sanchez-Tapias J-M (2011): Hepatitis $\mathrm{B}$ virus (HBV) reactivation in patients receiving tumor necrosis factor (TNF)-targeted therapy: analysis of 257 cases. Medicine 90, 359-371. https://doi.org/10.1097/ MD.0b013e3182380a76

Rajcani J (2007): Reactivation of latent DNA viruses during immunosuppression: basic contemplation. Acta Virol. 51, 77-100.

Ren W, Wu Z, Ma R, Liu Z, Wang Y, Wu L, Liu S, Wang Z (2017): Polymorphisms in the IL-17 Gene (rs2275913 and rs763780) Are Associated with Hepatitis B Virus Infection in the Han Chinese Population. Genet. Test. Mol. Biomarkers 21, 286-291. https://doi.org/10.1089/ gtmb.2016.0177

Rojas JM, Avia M, Martín V, Sevilla N (2017): IL-10: A Multifunctional Cytokine in Viral Infections. J. Immunol. Res. 2017: 6104054. https://doi.org/10.1155/2017/6104054

Shaheli M, Yaghobi R, Rezaeian A, Iravani Saadi M, Ramzi M (2015): Study of the Associations Between TT Virus Single and Mixed Infections With Leukemia. Jundishapur J. Microbiol. 8, e18212. https://doi.org/10.5812/ jim.8(4)2015.18212

Shang D, Lin Y, Rigopoulou I, Chen B, Alexander G, Allain JP (2000): Detection of TT virus DNA in patients with liver disease and recipients of liver transplant. J. Med. Virol. 61, 455-461. https://doi.org/10.1002/10969071(200008)61:4<455::AID-JMV7>3.0.CO;2-P 
Shibayama T, Masuda G, Ajisawa A, Takahashi M, Nishizawa T, Tsuda F, Okamoto H (2001): Inverse relationship between the titre of TT virus DNA and the CD4 cell count in patients infected with HIV. Aids 15, 563-570. https://doi. org/10.1097/00002030-200103300-00004

Talaat RM, Esmail AA, Elwakil R, Gurgis AA, Nasr MI (2012): Tumor necrosis factor-alpha-308G/A polymorphism and risk of hepatocellular carcinoma in hepatitis $\mathrm{C}$ virusinfected patients. Chin. J. Cancer 31, 29-35. https://doi. org/10.5732/cjc. 011.10258
Trifunović J, Miller L, Debeljak Ž, Horvat V (2015): Pathologic patterns of interleukin 10 expression-a review. Biochem. Med. 25, 36-48. https://doi.org/10.11613/BM.2015.004 Tzeng H-T, Tsai H-F, Chyuan I-T, Liao H-J, Chen C-J, Chen P-J, Hsu P-N (2014): Tumor necrosis factor-alpha induced by hepatitis $B$ virus core mediating the immune response for hepatitis B viral clearance in mice model. PLoS One 9, e103008. https://doi.org/10.1371/journal.pone.0103008

Wójtowicz A, Bochud P-Y (2016): Risk stratification and immunogenetic risk for infections following stem cell transplantation. Virulence 7, 917-929. https://doi.org/10.1080/2150 $\underline{5594.2016 .1234566}$ 